\title{
Expropriation as a Way for Protecting the Architectural Heritage
}

\author{
Svetlana Albu, Anna Leșan \\ Department of Engineering, Law and Real Estate Valuation, Technical University of Moldova, Chișinău, The Republic of Moldova \\ Email: svetlana.albu@emi.utm.md, anna.lesan@emi.utm.md
}

How to cite this paper: Albu, S., \& Leșan, A. (2021). Expropriation as a Way for Protecting the Architectural Heritage. Current Urban Studies, 9, 299-314.

https://doi.org/10.4236/cus.2021.92019

Received: May 23, 2021

Accepted: June 21, 2021

Published: June 24, 2021

Copyright $\odot 2021$ by author(s) and Scientific Research Publishing Inc. This work is licensed under the Creative Commons Attribution International License (CC BY 4.0).

http://creativecommons.org/licenses/by/4.0/

\begin{abstract}
The protection of the national cultural heritage consists of all measures of a scientific, legal, administrative, financial, fiscal, and technical nature, designed to ensure the identification, research, inventory, classification, preservation, security, maintenance, restoration, and enhancement of the national cultural heritage, in order to ensure democratic access to culture and the transmission of this heritage to future generations. This study examines achievements in the field of international heritage protection, the dynamics of preserved and endangered assets according to UNESCO data. The factors affecting the value of cultural heritage are analyzed by exemplifying their action in the Republic of Moldova. Expropriation is considered from the point of view of the possibility of protecting the architectural heritage. The practice of Turkey, the Russian Federation and Romania in protecting cultural heritage through expropriation or compulsory purchase of inadequately managed cultural property is covered in the research. Proposals are made on how to apply the best practices in the conditions of the Republic of Moldova.
\end{abstract}

\section{Keywords}

Protection, Preservation, Factors, Value, Expropriation of Cultural Heritage

\section{Introduction}

Currently in society, but also among professionals and people in positions of responsibility, two approaches to architectural heritage are being circulated. Some are supporting the development of urban settlements by destroying and replacing old buildings with modern ones, which are built according to the latest trends in architecture, construction, and market requirements. Others argue that history, cultural and architectural heritage must be preserved for new generations; that the past determines the present and shapes the future. The authors also affirm that it is important to preserve authenticity and national identity by pre- 
serving the architectural heritage. The architectural heritage is one of the structural elements of the nation with an enormous energy potential for spiritual development and national awareness in the multitude of nations and ethnicities existing in the world, as well as an anchor in the wave of change generated by the globalization process.

Regrettably, at the moment, the followers of the first position have gained ground in the Republic of Moldova.

Cultural heritage is of public interest through its essential impact on society due to the importance of its role in education, economy, and generally in the civilization of the entire society. This statute requires the regulation of its protection and the prevention of any damage to it, by establishing servitudes of property rights, whether public or private, over heritage assets and, at the same time, specific measures for the enhancement and preservation of these assets (Ilea, 2019).

The protection of the monuments of history and culture by the state bodies comprises various activities, which are materialized in the requirement and assurance of activities related to record keeping, enhancement, protection, safeguarding, preservation, and restoration. Attention is also paid to the extension of the material base, the use and accessibility of monuments for various research, the education of the young generation and the propagation of historical and cultural values. The protection of the state is exercised by Parliament, Government, the councils of district, municipality, city, and commune levels, as well as by the district presidents and mayors (Dimin, 2009).

However, "what should be" and what is done "de facto" are not always consistent in the Republic of Moldova. For example, the non-publication on the date of adoption in 1993 of the Register of State Protected Monuments led to the demolition of an impressive number of objects of architectural, cultural and historical value until 2010, when it was published in the Official Gazette of the Republic of Moldova. National legislation (Law, No. 413, 1999) provides that "Privatization of objects and properties that make up the national cultural heritage is prohibited", while providing that "(1) Monuments that are privately owned may be sold, donated or alienated with the mandatory notification of the state bodies in charge of monuments protection. When buying and selling monuments, the state has the right of pre-emption (Law, No. 1530, 1999). But this stipulation has often been violated or simply neglected.

Although the national legislation in force (Law, No. 1530, 1999) stipulates the cancellation of alienation transactions of monuments carried out in breach of the law, and provides for liability under the Civil Code, there is no precedence in the application of this measure.

In order to protect monuments in the form of real estate, the Law (Law, No. $1530,1999)$ specifies that monuments owners shall sign insurance contracts, indicating the value of the monuments and land from their protection areas established by an expert, but conclusive examples in this meaning do not exist. 
As a result, for a quarter of a century the cultural heritage of the Republic of Moldova is under aggression and is constantly decaying. During 2003-2006, 977 objects protected by the status of national and local level monuments and recorded in the Register of the Republic of Moldova were checked in Chisinau. Already in 2010 it was found that over $25 \%$ of them are either demolished or are in the process of active destruction (AIRM, 2011; Ştefăniță et al., 2010). In Chisinau, 82 monument sites are demolished (of which 44 were demolished between 1993 and 2006 and 38 between 2006 and 2012). 160 objects underwent illicit interventions. The total number of buildings that have suffered as a result of noncompliance with the legislation on the protection of monuments is 254 objects with the status of protected monument of national and local level (Ştefăniţă et al., 2011). This figure continues to rise, primarily due to existing corruption and non-compliance with legal provisions.

The lack of clear, unambiguous rules of urbanization, as well as the noncompliance with those that exist, have led to a considerable change of the image of the Historic Center and the deterioration of architectural monuments. The height noncompliance is observed in the neighborhoods located in the Historic Center. The construction of large, multi-storey modern buildings in close proximity to architectural monuments not only changes the visual appearance but also affects the resistance structure of old buildings by accelerating their degradation (Albu et al., 2020).

In this study we targeted to examine UNESCO's practices on the preservation and protection of cultural heritage, highlighting the existing dangers to which heritage objects are exposed and analyzing the factors that influence the value of architectural heritage in the Republic of Moldova. The created situation forced us to examine the applicability of the expropriation of immovable property of historical and architectural value as a last resort to save the heritage from destruction. In the paper we examine the practices of Romania, the Russian Federation and Turkey. Romania is the neighboring country of the Republic of Moldova with shared history, customs and cultural and architectural traditions, which promulgated the application of expropriation. The Russian Federation is examined as an example of the countries of the former USSR to which the Republic of Moldova was a party for 45 years. The Russian Federation requires the purchase of improvidently maintained cultural valuables. Turkey is examined as a model for the implementation of expropriation and the necessary procedural aspects, including how to accumulate funds for the preservation and protection of national heritage.

\section{Preservation and Protection of Cultural Heritage at International Level}

At international level, most normative acts, which refer to the legal regime of historical and cultural values, are adopted under the auspices of the UNESCO. The sphere of activity of this interstate organization includes solving a wide 
spectrum of problems of international scientific and cultural collaboration. In accordance with point 2 of Article 1 of its Statute, UNESCO "will: (c) Maintain, increase and diffuse knowledge: by assuring the conservation and protection of the world's inheritance of books, works of art and monuments of history and science, and recommending to the nations concerned the necessary international conventions; by encouraging cooperation among the nations in all branches of intellectual activity, including the international exchange of persons active in the fields of education, science and culture and the exchange of publications, objects of artistic and scientific interest and other materials of information" (UNESCO, 1945).

Since its establishment (London, 1945) UNESCO has been carrying out an intense legislative activity, consisting of the elaboration and adoption of conventions and recommendations on the protection of historical and cultural values. Its practical assets include the adoption of the most important international normative acts, such as: the 1954 Hague Convention, the 1972 Convention concerning the Protection of the World Cultural and Natural Heritage, as well as a whole series of specific recommendations.

The 1954 Hague Convention (Convention, 1954) is considered the first international document which has been recognized and approved worldwide, the main purpose of which is to preserve the historical and cultural heritage of the world's nations. As a result of this convention, the most important architectural monuments of world value are preserved annually (Figure 1).

However, the list of endangered monuments is not considerably reduced. Every year this list is supplemented, at the beginning of 2020 it included 36 cultural objects (UNESCO, 2021) (Figure 2).

The conditions which threaten heritage objects can be "ascertained" and "potential".

In case of ascertained danger, the property is faced with specific and proven imminent danger, such as: serious deterioration of materials; serious deterioration of structure and/or ornamental features; serious deterioration of architectural or town-planning coherence; serious deterioration of urban or rural space, or the natural environment; significant loss of historical authenticity; important loss of cultural significance (UNESCO, 2008).

In case of potential danger, the property is faced with threats which could have deleterious effects on its inherent characteristics. Such threats are, for example: modification of juridical status of the property diminishing the degree of its protection; lack of conservation policy; threatening effects of regional planning projects; threatening effects of town planning; outbreak or threat of armed conflict; threatening impacts of climatic, geological or other environmental factors (UNESCO, 2008).

\section{Factors Affecting the Value of Cultural Heritage}

The monitoring of endangered properties has made it possible to identify the 
factors that affect the Outstanding Universal Value. In 2008, the World Heritage Committee adopted a standard list of 14 primary factors (Figure 3), encompassing each a number of secondary factors (UNESCO, 2008).

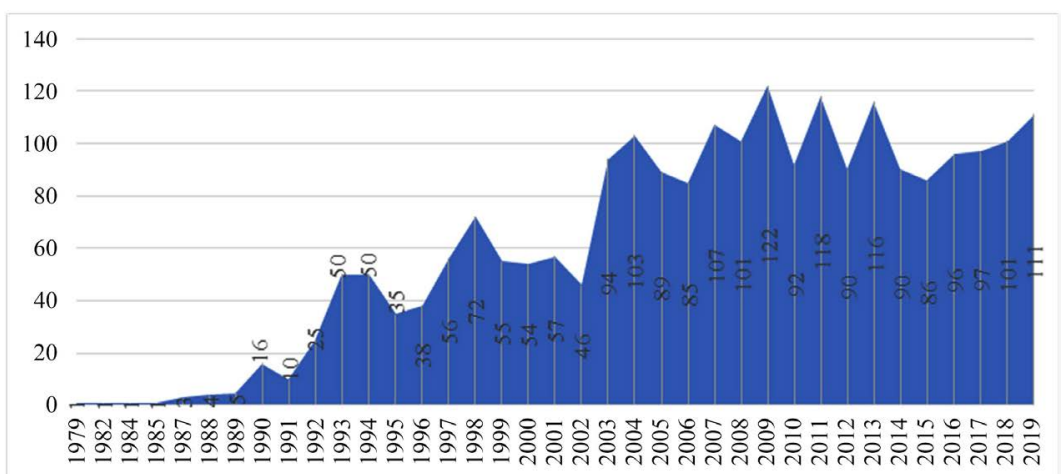

Figure 1. Number of properties preserved during the years 1979-2019 Source: (UNESCO, 2020).

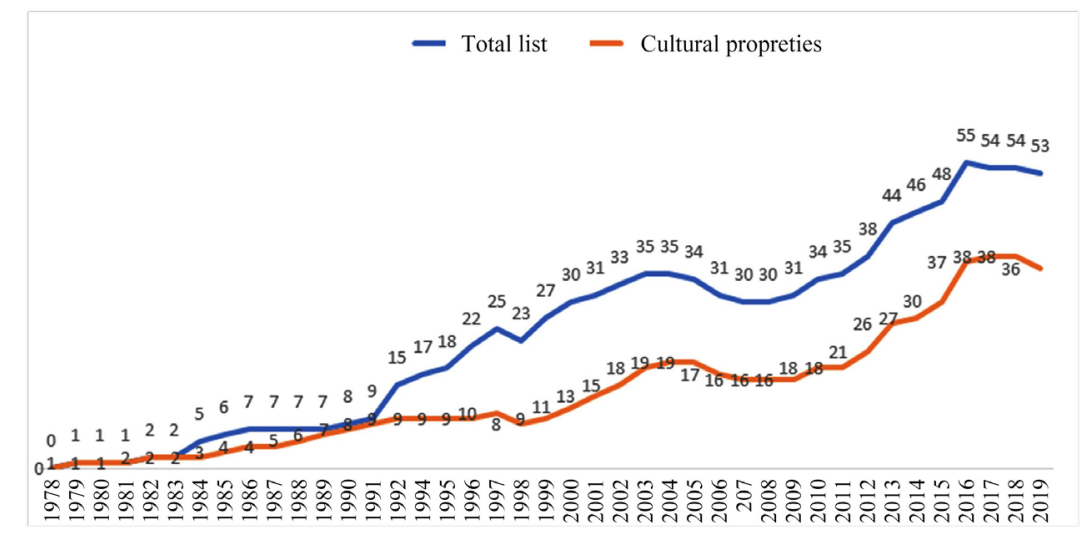

Figure 2. List of monuments in danger by year.

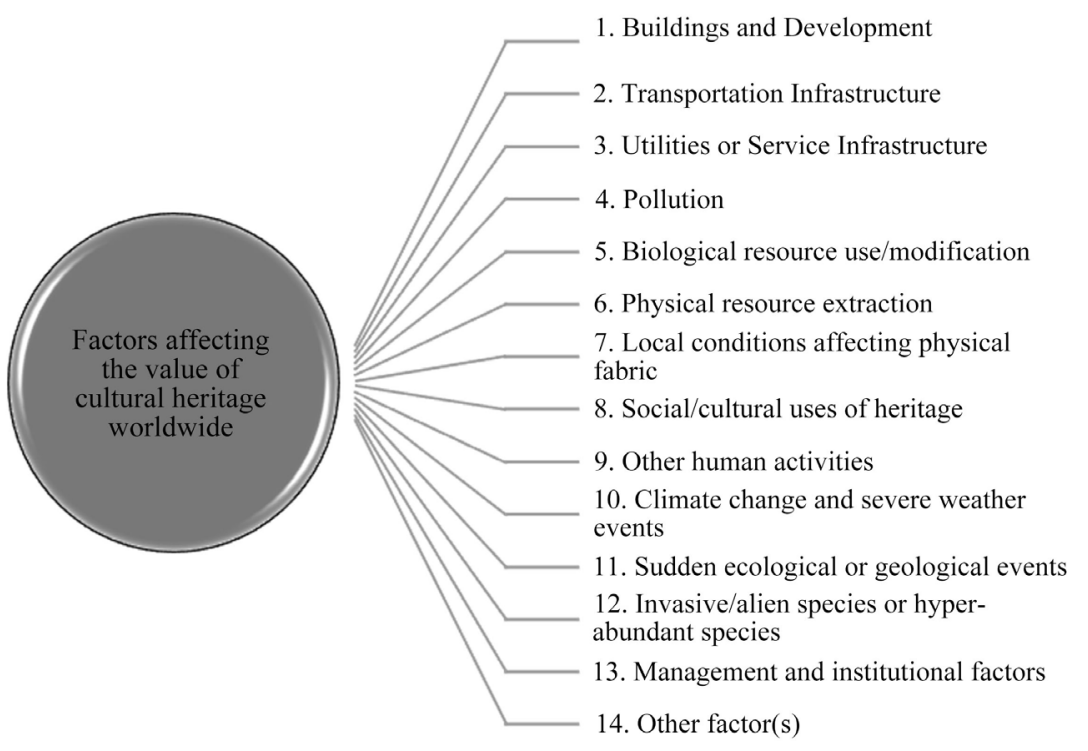

Figure 3. Factors affecting the value of cultural heritage. 
Analyzing the existing situation in the Republic of Moldova regarding the architectural heritage through in the light of the named factors, we find that the major influence on real estate is exerted by:

Buildings and Development. An extraordinary temptation for the owners of the architectural heritage has become the increase of the market value of the plots of land located in the Historic Center of Chisinau. In the suburbs the construction land is sold for $20-25$ thousand euro $/ 100 \mathrm{~m}^{2}$, while in the center of the capital the price is practically double (Albu \& Albu, 2014) (Lesan, 2020). Over the last decade, the prices of $100 \mathrm{~m}^{2}$ for some plots located in the Historic Center have exceeded 100 thousand euros. In the last year, the lack of free land has led to an increase in the price of construction plots in the center of the capital by an average of about $35 \%$. Currently, the "economic" aspect prevails in the consciousness of society. It is considered that buildings that do not bring income become useless and turn for owners into a burden, as any property must generate high income (for example Figure 4 and Figure 5).

Transportation Infrastructure. Road traffic for 10 years increased by an average of $60 \%$ and the number of cars increased by $68 \%$ (Table 1 ). The vehicle traffic intensity in the city center has also increased (NBS, 2021), causing considerable vibrations of the ground, which contributes to increasing the degradation of architectural monuments.
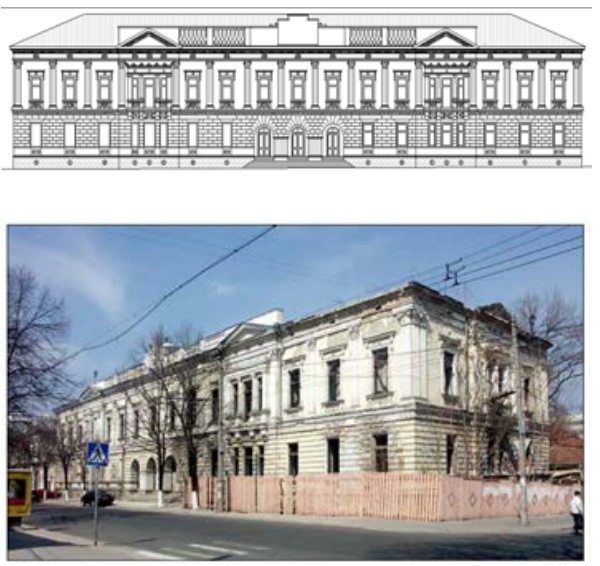

Figure 4. Architectural monument of national significance, 62 București Street (situation in 2010). Source: (Monuments, 2011).
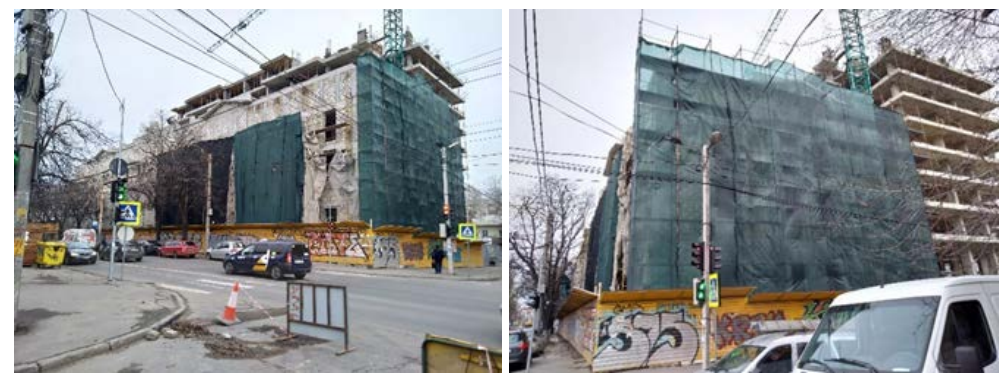

Figure 5. Architectural monument of national significance, 62 București Street. Source: original photo taken by the authors (March 2020). 
Table 1. Number of road vehicles registered at the end of the year, thousands.

\begin{tabular}{|c|c|c|c|c|c|c|c|c|c|c|c|c|}
\hline \multirow{2}{*}{ Tip } & \multicolumn{12}{|c|}{ Years } \\
\hline & 2009 & 2010 & 2011 & 2012 & 2013 & 2014 & 2015 & 2016 & 2017 & 2018 & 2019 & $2019 / 2009$ \\
\hline Goods road motor vehicles & 120.2 & 131.2 & 141.7 & 151.8 & 154.2 & 160.2 & 164.5 & 168.6 & 173.4 & 179.4 & 185.7 & 1.54 \\
\hline Buses and minibuses & 21.3 & 21.4 & 21.3 & 21.4 & 21.3 & 21.4 & 21.1 & 20.9 & 20.9 & 21.0 & 21.1 & 0.99 \\
\hline Cars (including taxi) & 386.4 & 404.3 & 427.0 & 456.4 & 487.4 & 512.5 & 529.8 & 546.8 & 588.1 & 616.8 & 648.8 & 1.68 \\
\hline Trailer and semi-trailer & 51.9 & 54.1 & 56.1 & 58.8 & 60.8 & 63.1 & 64.9 & 66.8 & 69.3 & 71.5 & 74.1 & 1.43 \\
\hline Total & 579.8 & 611.0 & 646.5 & 688.4 & 723.7 & 757.2 & 780.3 & 803.1 & 782.4 & 888.7 & 929.7 & 1.60 \\
\hline
\end{tabular}

Source: author's calculation based on National Bureau of Statistics data.

Utilities or Service Infrastructure. The engineering networks in the area of the location of the architectural heritage are outdated, often failing and generating trampling and compaction of ground that cause cracking of the walls.

Social/Cultural Uses of Heritage. Only buildings used as museums, religious sites, universities, schools, libraries are in a good or satisfactory condition and maintain their cultural/architectural value.

Other Human Activities. Characteristic of the Republic of Moldova are the illegal activities mentioned above and the deliberate destruction of the heritage. It is also important to mention the repair of buildings with modern "fashionable" materials, such as replacing the decor covering the walls of buildings with plaster or a layer of stones, changing the roof and replacing it with attics of 1 - 2 levels (Figure 6 and Figure 7), the construction of annexes, the replacement of wooden doors and windows with those of thermopan, closing balconies with glass and lining them (Figure 8). Thus, contemporary interventions lead to the disappearance of the "historic city".

Inadequate technologies and inappropriate materials lead to increased degradation of buildings included in the national cultural heritage. Exterior finishes executed in the last two decades have not lasted more than 5 years (Figure 9).

Sudden Ecological or Geological Events. The degradation and advanced wear of constructions in the capital of the Republic of Moldova is also due to the micro vibrations generated by the earthquakes, which are common in the area (Figure 10).

According to the data of the Institute of Geology and Seismology of the Republic of Moldova (IGS, 2021) in the period 2011-April 2021, 1030 earthquakes were recorded, including 728 earthquakes with a magnitude up to 3.5 on the Richter scale, 268 with a magnitude between 3.5 - 4.5, and 34 considerable earthquakes with a magnitude above 4.5 on the Richter scale (Table 2). The strongest earthquakes in this period with a magnitude of 5.8 occurred in October 2018 and September 2016.

Invasive/Alien Species or Hyper-Abundant Species. In case of architectural heritage, it is important to draw attention to perennial plantations. Chisinau was always famous for being a green and beautiful city. Unfortunately, the roots of mature trees not only destroy sidewalks and road, but also affect the foundations 
of the buildings (Figure 11). Given that in the Historic Center there are buildings without foundations, the roots of the trees affect the entire structure of these buildings.

Table 2. Number of earthquakes recorded in the Republic of Moldova, in the period 2011-2021.

\begin{tabular}{|c|c|c|c|}
\hline \multirow{2}{*}{ Period } & \multicolumn{3}{|c|}{ Number of earthquakes recorded with magnitude } \\
\hline & $2.8-3.5$ & $<4.5$ & $\geq 4.5$ \\
\hline January-March 2021 & 16 & 11 & $1(\mathrm{M}=4.5)$ \\
\hline January-December 2020 & 76 & 29 & $3(\mathrm{M}=5.2=5.0=4.6)$ \\
\hline January-December 2019 & 61 & 36 & $1(\mathrm{M}=4.5)$ \\
\hline January-December 2018 & 61 & 18 & $3(\mathrm{M}=5.8=4.5=4.6)$ \\
\hline January-December 2017 & 68 & 29 & $4(\mathrm{M}=4.9=4.6=4.7=5.0)$ \\
\hline January-December 2016 & 80 & 34 & $2(\mathrm{M}=5.4=5.8)$ \\
\hline January-December 2015 & 98 & 36 & $4(\mathrm{M}=4.5=4.9=4.6=4.6)$ \\
\hline January-December 2014 & 85 & 21 & $8(\mathrm{M}=4.5=5.7=4.8=4.6=4.6=5.0=4.6=4.7)$ \\
\hline January-December 2013 & 74 & 23 & $3(\mathrm{M}=4.7=5.5=4.5)$ \\
\hline January-December 2012 & 63 & 21 & $2(\mathrm{M}=4.8=4.6)$ \\
\hline January-December 2011 & 46 & 10 & $3(\mathrm{M}=4.8=4.5=4.9)$ \\
\hline TOTAL & 728 & 268 & 34 \\
\hline
\end{tabular}

Source: developed by the authors based on data from the Institute of Geology and Seismology of the Republic of Moldova.

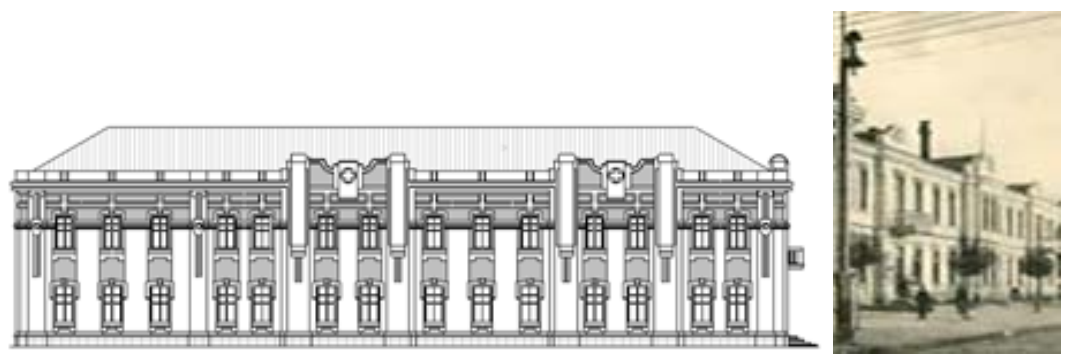

Figure 6. Architectural monument of national significance (initial condition), 46 Vlaicu Pârcălab Street (corner with Veronica Micle Street). Source: (Monuments, 2011).

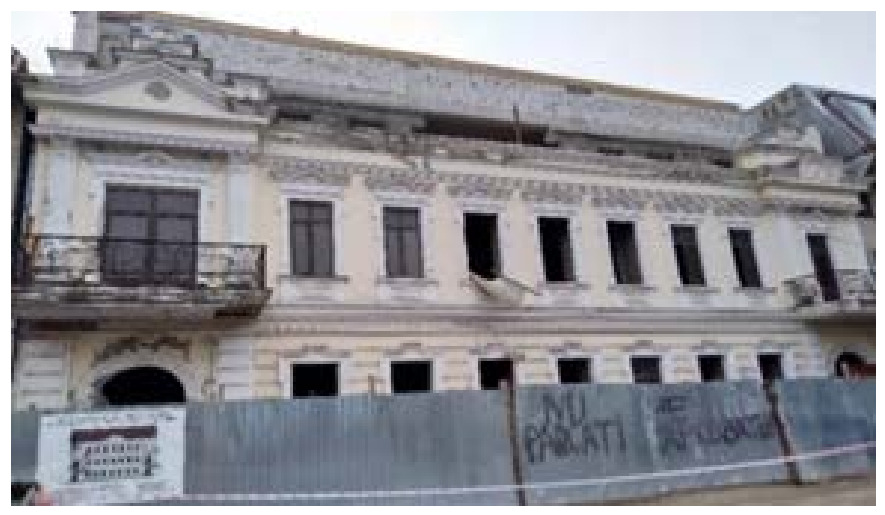

Figure 7. Reconstruction of the monument from Figure 6 with the addition of a level and attic. Source: original photo taken by the authors (March 2020). 


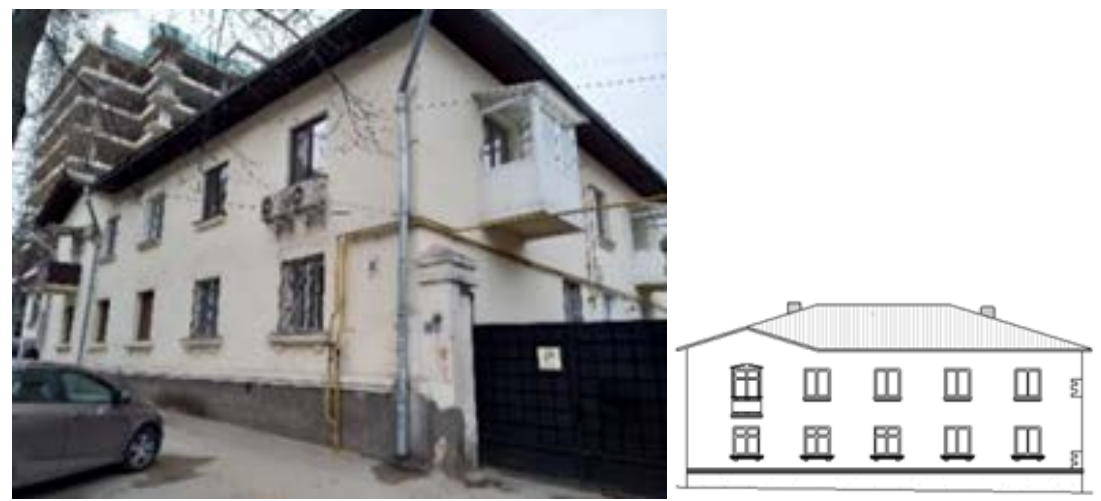

Figure 8. Architectural monument of local significance, 41 Vlaicu Pîrcălab Street (white and brown thetmopan windows; remodeled balconies). Source: original photo taken by the authors (March 2020), (Monuments, 2011).
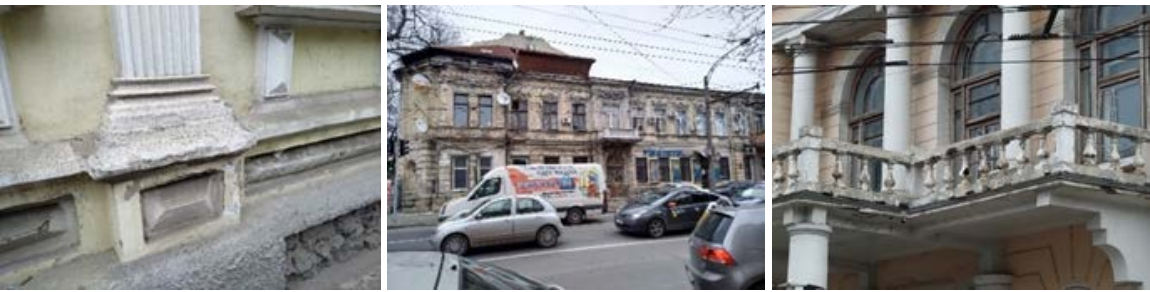

Figure 9. The condition of the facades of the architectural monuments located on $\mathrm{Bu}$ charest Street, 10 - 15 years after the repairs. Source: original photos taken by the authors (March 2020).
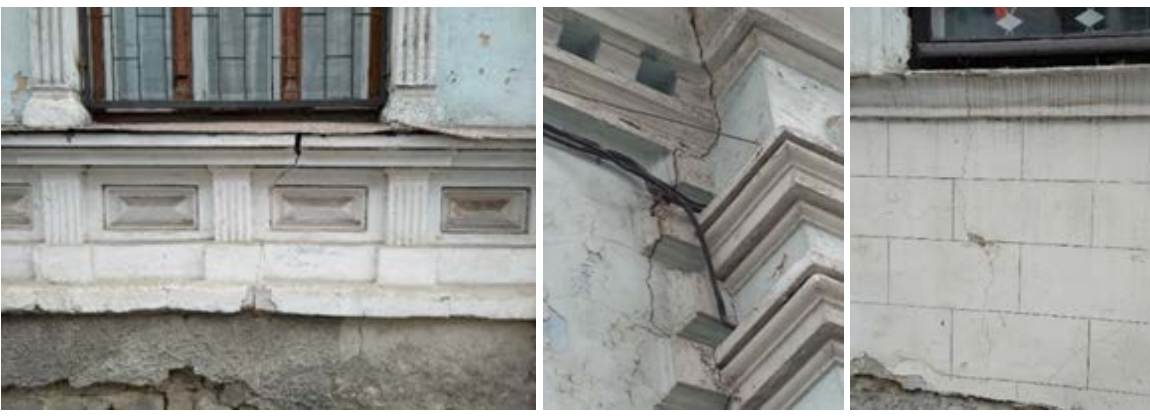

Figure 10. Cracks in walls of architectural monuments. Source: original photos taken by the authors (March 2021).

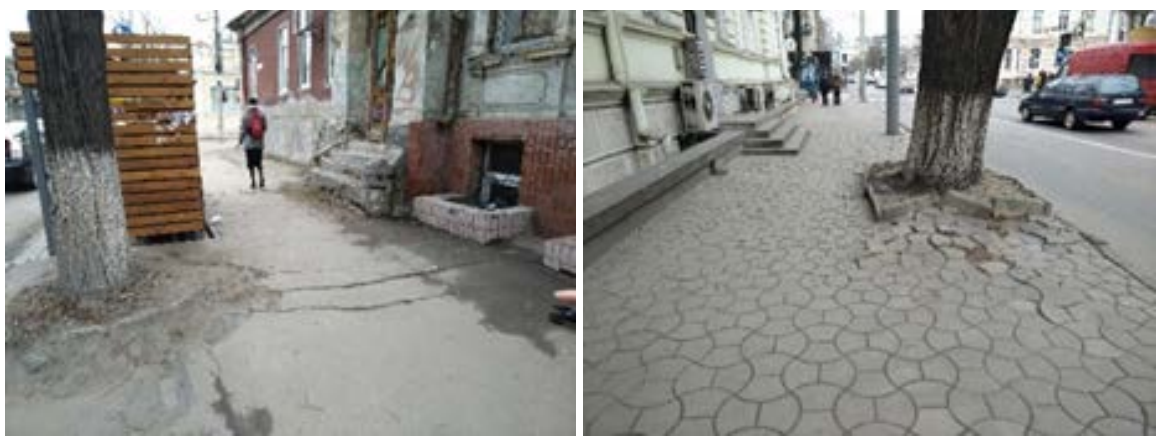

Figure 11. Damage to sidewalks by tree roots affecting the architectural monuments. Source: original photos taken by the authors (March 2020). 
Management and Institutional Factors. The lack of clear, unambiguous rules of urbanization, as well as the non-compliance with those that exist, have led to the deterioration of architectural monuments. Currently, the height noncompliance is observed in the neighborhoods located in the Historic Center of Chisinau (Figures 12-14). The construction of large, multi-storey modern buildings in close proximity to architectural monuments not only changes the visual appearance but also affects the resistance structure of old buildings by accelerating their degradation.

\section{Expropriation of Cultural Heritage}

As it was shown, the architectural heritage is influenced by various factors that generate both "ascertained" and "potential" dangers. The loss or decrease of the historical-cultural value is an international problem on which teams of specialists from different fields are working. One of the ways of protecting the cultural heritage is the expropriation with its subsequent preservation.
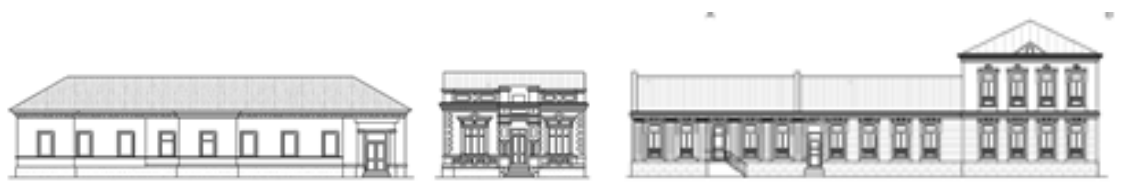

Figure 12. Original plan of the ensemble of architectural monuments of local significance, 10 Veronica Micle Street and 55 A Vlaicu Pârcălab Street. Source: (Monuments, 2011).
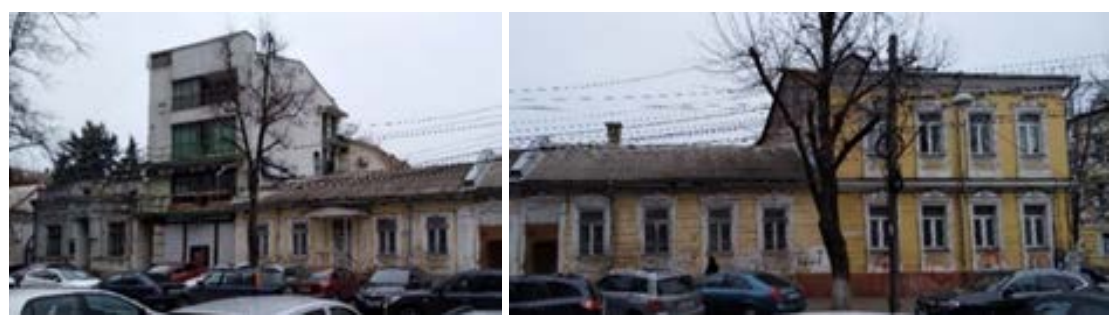

Figure 13. New construction between the buildings of the ensemble from Figure 12. Source: original photos taken by the authors (March 2021).
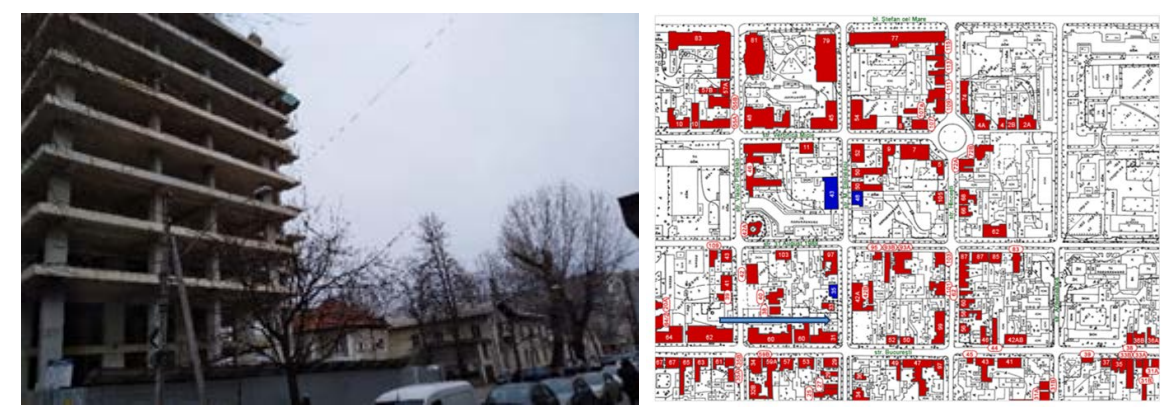

Figure 14. New construction in the Historic Center of Chisinau (neighboring buildings with 1 - 3 levels). The buildings with national and local architectural value are shown in red on the topographic map. Source: original photos taken by the authors (March 2020), (Monuments, 2011). 
The possibility of expropriating a protected property is included in the Council of Europe's Granada Convention of 1985 for the protection of Europe's architectural heritage, article 4, which stipulates that each Party shall prevent the disfigurement, dilapidation, or demolition of protected properties. To this end, each Party undertakes to introduce, if it has not already done so, legislation which: (c) permits public authorities to require the owner of a protected property to carry out work or to carry out such work itself if the owner fails to do so; (d) allows compulsory purchase of a protected property (Granada, 1985).

Each country decides its own way of implementing the provisions. For example, Turkey, Russia, and Romania have a different approach to preserving damaged, degraded, and inadequately managed heritage assets.

In Turkey, in order to implement the provisions of Article 12 paragraph 8 of the Law on the Protection of Cultural and Natural Assets from 21/7/1983, the Regulation on the Contribution Fee for the Conservation of Immovable Property was developed in 2005 (Turkey, 2005), the updated version entered into force on August 22, 2015. The purpose of current regulation (Turkey, 2015), stipulated in Article 1, is to determine the application principles of a contribution fee that shall be imposed at the rate of $10 \%$ of the real estate tax accrued, in order to protect and evaluate the immovable cultural assets located in the areas of responsibility of municipalities and special provincial administrations.

Article 7 stipulates: "(2) Contributions shall be used by the Governorship on an equitable basis, taking into account the number of immovable cultural assets, the current situation, and their significance in the cultural values of the province, on the condition that the amount collected does not exceed $95 \%$ of the cost of planning, projects, implementation and expropriation works (including VAT) prepared by municipalities, provincial private administrations and investment monitoring and coordination presidencies for the protection and evaluation of immovable cultural assets, provided that the amount collected in the contribution account is sufficient." (Russian Federation, 2021).

In order to initiate the expropriation procedure, project design, planning and implementation within the projects for the preservation and evaluation of immovable cultural property, the government or administrations prepare a series of necessary documents (Table 3 ).

The following order of priority is recommended for the evaluation of applications for expropriation, project design, planning, and implementation.

a) Immovable cultural property constituting urgency on account of its condition:

1) Those with ongoing repair;

2) Those requiring material, bearing system and ground reinforcement.

b) Development plans and conservation solutions,

c) Projects and activities in areas defined as special areas for the implementation of conservation projects,

d) Projects and activities for street rehabilitation and landscaping, 
Table 3. Documents necessary for the initiation of protection and expropriation of cultural heritage procedure.

\begin{tabular}{|c|c|c|}
\hline a) Project development and planning & b) Project implementation & c) Expropriation \\
\hline $\begin{array}{l}\text { 1) Conservation plan: } \\
\text { - Decision of the Conservation Council indicating the borders of the } \\
\text { planning area of the urban conservation site and the approved map } \\
\text { section, }\end{array}$ & $\begin{array}{l}\text { 1) For urban design and street } \\
\text { rehabilitation projects: } \\
\text { - Implementation project approved by the } \\
\text { Conservation Council, }\end{array}$ & $\begin{array}{l}\text { - Registration decision } \\
\text { regarding the property to be } \\
\text { expropriated, }\end{array}$ \\
\hline $\begin{array}{l}\text { - Technical report, } \\
\text { - Decision of the municipal assembly, } \\
\text { - Estimated cost of the project. }\end{array}$ & $\begin{array}{l}\text { - Panoramic images and photos in the } \\
9 \times 13 \text { dimensions of the area, } \\
\text { - Work schedule, }\end{array}$ & $\begin{array}{l}\text { - Finalised expropriation } \\
\text { decision, }\end{array}$ \\
\hline & - Estimated cost of the project. & - The cost of expropriation. \\
\hline \multicolumn{3}{|l|}{ 2) For urban design and street rehabilitation projects: } \\
\hline $\begin{array}{l}\text { - Decision of the Conservation Council indicating the borders of the } \\
\text { project area and the elements to be conserved on site, as well as the } \\
\text { approved map section, }\end{array}$ & $\begin{array}{l}\text { 2) For single building project } \\
\text { implementation: } \\
\text { - Implementation project approved by the }\end{array}$ & \\
\hline $\begin{array}{l}\text { Panoramic pictures showing the project area, its periphery, and } \\
\text { important buildings, as well as photos taken with minimum dimensions } \\
\text { of } 9 \times 13 \text {, }\end{array}$ & $\begin{array}{l}\text { Conservation Council, } \\
\text { - Restoration report, } \\
\text { - Work schedule, }\end{array}$ & \\
\hline - Estimated cost of the project. & $\begin{array}{l}\text { - Photos showing the inner, outer parts and } \\
\text { periphery of the building, }\end{array}$ & \\
\hline 3) For projects at the scale of a single building: & - Estimated cost of the project. & \\
\hline \multicolumn{3}{|l|}{$\begin{array}{l}\text { - Decision of the Conservation Council on the registration of the } \\
\text { building, }\end{array}$} \\
\hline \multicolumn{3}{|l|}{$\begin{array}{l}\text { - The scaled map and map section showing the position, periphery, and } \\
\text { location of the building, }\end{array}$} \\
\hline - Photos showing the inner, outer parts and periphery of the building, & & \\
\hline - Estimated cost of the project. & & \\
\hline
\end{tabular}

e) Projects and activities relating to immovable cultural property owned by the public and monumental buildings in urban sites and conservation areas,

f) Management plan,

g) Projects and activities concerning other immovable cultural property,

h) Expropriations (Turkey, 2015).

Expropriation is not stipulated in The Russian Federation laws. The Civil Code requires the "Purchase of Improvidently Maintained Cultural Valuables". This aspect is regulated by Article 240, which provides that: "In instances when the owner of cultural valuables relegated in accordance with a law to [the category of] specially valuable and protected by the State improvidently maintains these valuables, which threatens them with their losing their significance, such valuables may by decision of a court be withdrawn from the owner through purchase by the State or sale at a public sale.

In the event of the purchase of cultural valuable the owner shall be compensated their value in the amount established be agreement of the parties, and in the event of a dispute, by a court. In the event of the sale at a public sale the amount received from the sale shall be transferred to the owner less the expenses for holding the public sale" (Russian Federation, 2021).

In Romania according to Law No. 422/2001 on the protection of historical 
monuments, with subsequent amendments and completions, article 10, paragraph (3) provides that: "The expropriation for public utility cause of historical monuments and of their protection areas or the establishment of easements may be initiated and enforced only with the endorsement of the Ministry of Culture and National Heritage." (Romania, 2006)

Taking into account the high number of historic monument buildings in a state of degradation, the Romanian authorities decided in 2018 to include works for the protection and restoration of national heritage buildings and works of local public interest to preserve and protect degraded heritage buildings in the category of works of public utility. The regulation is included in Law No $233 / 2018$, for the amendment and completion of Law No 255/2010 on expropriation for a cause of public utility, necessary for achieving some objectives of national, country, and local interest (Romania, 2010).

This measure gives public authorities the possibility to quickly transfer into public ownership of the state or administrative-territorial units, the buildings categorized as historical monuments, which are in a state of degradation and in need of urgent repairs, through the simplified expropriation procedure.

These decisions demonstrate an increased state interest in the protection of historical monuments, the outcomes depend on the particular actions that the authorities implement for the rehabilitation of many historic monuments in a state of degradation and the funds allocated for this purpose.

In the Republic of Moldova in 2017 a draft Law on the Protection of Historical Monuments was developed, which takes into account the provisions of the conventions, charters and recommendations of UNESCO/ICOMOS and of the Council of Europe on the field of cultural heritage. Article 25 paragraph 5 stipulates that the responsibilities of the Ministry of Education, Culture and Research include the initiation, when necessary, or the request from the second level local public authorities, as appropriate, the expropriation for a cause of public utility of historical monuments, in order to save them from destruction and degradation (Moldova, 2017).

Regrettably, this project was not adopted, as a consequence there are no cases in the Republic of Moldova in which a building in the category of historical monuments was expropriated.

Examples of expropriation exist in the neighboring country, Romania. The City Hall of the Romanian capital plans to expropriate historic buildings, abandoned by the owners; to consolidate them; to introduce them in the circuit and to develop in them hotel businesses. Among the expropriated historical heritage assets are:

1) The Danube hotel has not been used for more than 20 years, the building has almost 2700 square meters, it was built in 1938, it was damaged in the earthquake of 1977, the city paid for expropriation almost 1.6 million euros;

2) The famous Bristol Hotel, built in 1894 in the University Square with an area of 1000 square meters, is a construction of the architect Xenopol. It will be 
the first hotel owned by Bucharest City Hall. Its restoration could cost more than 4.5 million euros. At the moment the work is started on one of the buildings;

3) The house of Pompiliu Eliade was built in 1907 after the drawings of Bogdan Petriceicu Hasdeu. In order not to be completely destroyed, it was surrounded by a fence. The city claims that for expropriation it paid to the owners, who left the building in ruins, compensations of almost 1 million euros. The house will be able to enter the tourist circuit of Bucharest, as a space for exhibitions and cultural events only after it will be rehabilitated.

An important aspect is the fact that the amount of compensation is not set by the City Hall, it cannot impose a minimum or maximum amount for a certain real estate required to be expropriated. The amount of compensation paid for expropriations is calculated by the specialists of a law company (ProTV, 2020).

\section{Conclusions and Proposals}

Factors affecting the value of architectural heritage in the Republic of Moldova are buildings and development; transportation infrastructure; utilities or service infrastructure; social/cultural uses of heritage; other human activities; ecological or geological events; invasive species; management and institutional factors.

The influence of factors that generate "ascertained" dangers cannot be excluded, they can only be reduced by restrictive actions (limiting road traffic, imposing fines for incorrect/inappropriate interventions in the structure/facades of buildings, etc.) or providing some facilities (exemption from property tax, offering preferential loans, etc.).

At the same time, the "potential" dangers generated by the group of institutional and management factors can be eliminated through an appropriate legislative framework and a functional executive framework.

- It is important to approve and implement the Law on the Protection of Historical Monuments, which is at the draft level. This law will allow the implementation of the provisions of international conventions, in particular, those issued by UNESCO, which represent the best practice worldwide.

- It is necessary to include in the legislation of the Republic of Moldova the provision of compulsory purchase of inadequately managed cultural assets.

- At the same time, it is crucial to stipulate the obligation to expropriate real estate with historical and architectural value as a last resort to save the heritage from destruction. Mainly for situations where the owner intentionally creates conditions for deterioration of cultural heritage.

- Lastly, it is important to amend the Fiscal Code and to include the use of a part of the real estate tax (for example 10\%) for works/actions intended to protect the cultural heritage.

\section{Acknowledgements}

The research was carried out within the project 20.80009.0807.34. Increasing the value of architectural heritage of the Republic of Moldova. 


\section{Conflicts of Interest}

The authors declare no conflicts of interest regarding the publication of this paper.

\section{References}

AIRM (2011). Report of the Agency for Inspection and Restoration of Monuments Based on Inspections Carried Out in the 32 Districts and 3 Municipalities of the Republic of Moldova (2010-2011).

https://ru.scribd.com/doc/80778569/Raportul-Agenției-De-Inspectare-și-Restaurare-aMonumentelor-2011

Albu, S. et al. (2020). Patrimoniu arhitectural: Aspecte legale, tehnice și economice [Architectural Heritage: Legal, Technical and Economic Aspects]. Chișinau: MS Logo.

Albu, S., \& Albu, I. (2014). Piața imobiliară: Lucrare științifico-metodică privind analiza pieții imobiliare (exemplul municipiul Chișinau) [Real Estate Market: Scientific-Methodical Work on Real Estate Market Analysis (on the Example of Chisinau Municipality)]. Chisinau: Tehnica-UTM.

Convention (1954). Convention for the Protection of Cultural Property in the Event of Armed Conflict with Regulations for the Execution of the Convention 1954.

http://portal.unesco.org/en/ev.php-URL_ID=13637\&URL_DO=DO_TOPIC\&URL_SE CTION=201.html

Dimin, V. (2009). Standarde de protecție a bunurilor culturale. Protecția juridică a valorilor culturale în Republica Moldova [Standards for the Protection of Cultural Property. Legal Protection of Cultural Values in the Republic of Moldova]. Acad. Ştefan cel Mare a MAI al RM.

Granada (1985). Convention for the Protection of the Architectural Heritage of Europe, ETS No. 121.

https://www.coe.int/en/web/conventions/full-list/-/conventions/treaty/121

IGS (2021). Earthquakes Recorded by the Network of Seismic Stations of the Institute of Geology and Seismology. https://igs.asm.md/node/115

Ilea, I.-L. (2019). Raport de inventariere și analiză legislație Titlul I-Dispoziții generale. Proiect: Monumente istorice, planificare strategică și politici publice optimizate. Activitatea A1.1 Inventarierea și analiza legislației în domeniul patrimoniului cultural [Report on Inventory and Analysis of Legislation Title I-General Provisions. Project: Historical Monuments, Strategic Planning and Optimized Public Policies. Activity "A1.1 Inventory and Analysis of Legislation in the Field of Cultural Heritage"].

Law No. 1530 of June 22, 1993 on the Protection of Monuments. In: Official Gazette No. 1 of January 30, 1994, Article 3.

https://www.legis.md/cautare/getResults?doc_id=119178\&lang=ro

Law No. 413 of May 27, 1999 on Culture. In: Official Gazette No. 83-86, Article 401. https://www.legis.md/cautare/getResults?doc_id=108404\&lang=ro

Lesan, A. (2020). Dezvoltarea pieții imobiliare a Republicii Moldova prin prisma analizei repartizării teritoriale după regiunile de dezvoltare [Development of the Real Estate Market of the Republic of Moldova through the Analysis of the Territorial Distribution by Development Regions]. Chișinau: Tehnica-UTM.

Moldova (2017). Law on the Protection of Historical Monuments (Draft). https://particip.gov.md/ru/document/stages/proiect-hg-cu-privire-la-aprobarea-proiect ului-legii-protejarii-monumentelor-istorice/4609 
Monuments (2011). Monumentele de arhitectură în Centrul Istoric al Chişinăului [Architectural Monuments in the Historic Center of Chisinau].

http://www.monument.sit.md

NBS (2021). National Bureau of Statistics. Transport. https://statistica.gov.md/category.php?l=ro\&idc $=138$

ProTV (2020). City Hall Plan for Dilapidated Historical Monuments. Pro TV News. https://stirileprotv.ro

Romania (2006). Law No. 422 of July 18, 2001, on the Protection of Historical Monuments. Official Gazette No. 934 of November 20, 2006. Legislative Portal. http://legislatie.just.ro/Public/DetaliiDocument/29761

Romania (2010). Law No 255 of December 14, 2010, on Expropriation for a Cause of Public Utility Necessary to Achieve Objectives of National, County and Local Interest. Official Gazette No. 853 of December 14, 2010. Legislative Portal. http://legislatie.just.ro/Public/DetaliiDocument/124540

Russian Federation (2021). Гражданский кодекс Российской Федерации (часть первая) [Civil Code of the Russian Federation (Part One)] of November 30, 1994 No. 51-FZ (as Amended on March 09, 2021). Консультант Плюс.

http://www.consultant.ru/document/cons_doc_LAW_5142/7477551d2c612c6cd31f819 $\underline{\text { f007294690c7a456c }}$

Ştefăniță, I. et al. (2010). Cartea neagră a patrimoniului arhitectural al municipiului Chişinău [The Black Book of the Architectural Heritage of Chisinau Municipality]. Chişinău.

https://issuu.com/ghenador/docs/cartea_neagra_a_patrimoniului_cultural_al_municip i

Ştefăniță, I. et al. (2011). Patrimoniul cultural al Republicii Moldova: De la realitate la necessitate [The Cultural Heritage of the Republic of Moldova: From Reality to Necessity]. Chişinău.

https://ru.scribd.com/document/76025513/Patrimoniul-cultural-al-RM-De-la-realitate -la-necesitate

Turkey (2005). Regulation on the Contribution Fee for the Conservation of Immovable Cultural Property. Official Gazette of April 13, 2005.

https://zh.unesco.org/sites/default/files/turkey_regulationcontributionfeeconservationi mmovableculturalproperty_18_entof

Turkey (2015). Regulation on the Contributions for the Conservation of Immovable Cultural Property. Official gazette of August 22, 2015.

https://www.resmigazete.gov.tr/eskiler/2015/08/20150822-18.htm

UNESCO (2008). List of Factors Affecting the Properties.

http://whc.unesco.org/en/factors

UNESCO (2020). State of Conservation. http://whc.unesco.org/en/soc/?sitescategory=1\&action=list\&mode=chart

UNESCO (2021). List of World Heritage in Danger. https://whc.unesco.org/en/danger

UNESCO (1945). Constitution. http://portal.unesco.org/en/ev.php-URL_ID=15244\&URL_DO=DO_TOPIC\&URL_SE CTION=201.html 